\title{
Efficacy of co-creation and mastering on perceived value and satisfaction in experiential consumption
}

Nina K Prebensen and Jinghua Xie

UiT The Arctic University of Norway

\begin{abstract}
This study explores the effects of participation, namely co-creation and mastering, on the perceived value of consumers' experience and satisfaction. Co-creation comprises both physical and psychological (mental) participation, and mastering represents consumers' self-perceived knowledge and skills in taking part in experiential activities. Adventure tourism is chosen as an empirical case to put forward participation practices and their effects in an experiential consumption setting. The present work uses a logit model for the model estimation that considers the relationships between participation and satisfaction directly and through value perception. The study results reveal that consumers' mastering and psychological co-creation are significant for value perception. The study also finds value perception to mediate the relation between participation and satisfaction. Consequently, consumers' participation augments satisfaction by creating value in the experience. This study contributes to the theory in two ways. First, it reveals the importance of including the mastering and co-creation dimensions in acknowledging consumers as resource integrators for value creation in experiences. Second, the study shows that satisfaction in experiential consumption evolves through consumers' participation in creating their own perceived value of the experience, indicating innovation potential for the tourism industry.
\end{abstract}

\section{Key words: co-creation, mastering, perceived value, satisfaction, experiential consumption}




\section{Introduction}

Consumers' role as resource integrators in value creation processes has received increased attention in the recent literature (e.g., Baron \& Harris, 2008; Navarro, Andreu, \& Cervera, 2014; Prebensen, Kim, \& Uysal, 2016; Vargo \& Lusch, 2004). According to these scholars, research reveals that consumers partake in co-creating value with employees, other consumers, and the setting (e.g., Carù \& Cova, 2003; Cova \& Salle; 2008; Prebensen \& Foss, 2011; Verhoef, Reinartz, \& Krafft, 2010). Consumers who participate in creating value in the consumption process are shown to be more satisfied than passive agents (e.g., Navarro, Llinares, \& Garzon, 2016; Prebensen et al., 2016; Troye \& Supphellen, 2012). Although the literature exposes the vital role of consumers in value creation processes, more knowledge regarding how and where value is created in the consumption processes is required (Rihova, Buhalis, Moital, \& Gouthro, 2015). Hence, this article explores the process of value co-creation by studying the direct effects of participation on value perception and satisfaction and the indirect effects of participation on satisfaction through value perception (mediating effect) in a setting of adventure tourism consumption. Researchers delineate active participation in consumption in both physical and psychological terms (Bertella, 2014; Minkiewicz, Evans, \& Bridson, 2013; Prebensen \& Foss, 2011). Physical participation includes body movements (Campos, Mendes, Oom do Valle, \& Scott, 2016), whereas psychological participation concerns a person's cognitive actions, such as learning, collecting, and sharing information and knowledge acquisition (Kolb, 1984; Yi \& Gong, 2013). Both co-creation patterns are suggested to result in feelings such as fun, happiness, and contentment (Holbrook, 2000).

In the process of value co-creation, consumers make efforts to use competence or skills, delineated as operant resources (see Constantin \& Lusch, 1994, for a discussion), in their chosen activities. Consumers' perception of their own competence and skills can be denoted as selfperceived mastering, that is, as the ability to perform a certain experiential activity or task, such as hiking, canoeing, or dogsledding. Previous experience, knowledge, and personal skills in performing an activity are subsequently important aspects regarding self-perceived mastering. The present work adopts this perspective and includes self-perceived mastering (i.e., how consumers perceive their knowledge and skills regarding the performance of a certain activity) as an antecedent of perceived experience value.

Consumers who partake in co-creation in consumption processes expect various types of benefits, such as hedonic, cognitive (i.e., information), social, and personal benefits (Nambisan \& 
Baron, 2009). These benefits are delineated as the perceived consumer value by Sheth, Newman, and Gross (1991). The existing literature clearly identifies consumers' perceived value as an important antecedent to their satisfaction in experiential consumption, such as the consumption of culture, heritage, leisure, sports, and tourism (e.g., Cronin, Brady, \& Hult, 2000; Gallarza \& Saura, 2006; Prebensen et al., 2016; Williams \& Soutar, 2009).

The study described in this paper tests the effects of co-creation and mastering on the perceived value of consumers' experience and satisfaction. To test the model in experiential consumption, adventure tourism is chosen as a study case. In a review of adventure tourism, Sung, Morrison, and O'Leary (1996) identify six major components of the notion of adventure activity, environment, experience, motivation, performance, and risk - and find that activity is the most important variable for defining adventure travel. Martin and Priest (1986) characterize adventure tourism as residing in the interplay of competence and risk. Walle (1997), however, suggests viewing adventure in terms of a quest for insight and knowledge rather than risk in adventure tourism. Despite their different views, these scholars show that adventure tourists hold various motivations for engaging in such endeavours.

In experiential consumption adventure tourists travel because they want to partake in both the production and the consumption of such experiences. Our assumption is that, since consumers in experiential settings are resource providers and participants in value creation (Vargo \& Lusch, 2004), co-creation and mastering will enhance their perceived value and subsequently increase their satisfaction. We also assume perceived value to function as a mediating variable in experiential consumption.

The theoretical underpinning of the present work is based on the service-dominant logic perspective, in which the consumer is imperative in the value creation process (e.g., Grönroos \& Voima, 2013; Vargo \& Lush, 2004, 2006). Additionally, this work takes the stand that a consumer in experiential consumption may search for various experiences producing different kinds of feelings (e.g., Hirschman \& Holbrook, 1982; Holbrook, 1987, 2000, 2007), namely hedonic and eudaimonic feelings. While hedonic feelings are described in the literature as experiences during behaviour that is familiar or easily managed, eudaimonic feelings include emotions such as interest, immersion, and engagement (Vitters $\varnothing, 2011$ ). Eudaimonic feelings are typically experienced during the pursuit of important goals and in attempts to overcome obstacles (Panksepp, 2005; Vitters $\varnothing, 2011$ ). 
The present work contributes in several ways. First, it provides detailed insights into cocreation, mastering, and dimensions of the value creation process as consumers take part in activities to create value and satisfaction for themselves. Thus, the paper enriches the theoretical and empirical perspectives of value co-creation. Second, it identifies how co-creation and mastering can increase different dimensions of experience value in adventure tourism. Third, it provides insights regarding the process of consumers' participation in generating satisfaction through the process of co-creating value. The present research subsequently fills a void in the research regarding the process of co-creating value in experiential consumption (Vargo \& Lusch, 2004).

The paper is structured as follows. The next section presents a summary of the relevant literature on perceived value and satisfaction and the relationship between the two constructs. Next, co-creation and mastering are delineated and hypotheses regarding the relationships between physical co-creation, psychological co-creation, mastering, and value perception and satisfaction are suggested. The data and research methods are then presented, followed by a discussion of the results from the model. The paper concludes with the main findings and recommendations for further research.

\section{Literature review and hypothesis development}

\subsection{Perceived experience value and satisfaction}

Consumer perceived value in experiential consumption is about 'value-in-use', because the consumer is personally present in the situation in which the experience value is co-created (Grönroos, 2011). Consumer perceived value as a theoretical and empirical construct has received increasing attention in marketing and tourism research in the last three decades (e.g., Bolton \& Drew, 1991; Hirschman \& Holbrook, 1982; Holbrook, 1987, 2000, 2007; Williams \& Soutar, 2009). Holbrook (1987, p. 128) states that "ideas, events, or any other entities that can be acquired, used, or disposed in ways that potentially provide value" are important when a consumer is experiencing a product or a service. The much-cited view of Holbrook and Hirschman (1982, p. 132) - "consumption experience as a phenomenon directed toward the pursuit of fantasies, feelings and fun" - is therefore imperative in understanding value creation in experiential contexts.

Value is relativistic and comparative in nature. Perceived experience value therefore deals with continuously changing personal, unique, and individual needs (Addis \& Holbrook, 2001). 
The underlying motivations to create and co-create a state of well-being that provides satisfying experiences in experiential consumption are therefore education, enjoyment, socialization, or relaxation (Carù \& Cova, 2003). Consumers make choices based on many value dimensions, which may vary according to their personal needs and the setting (Sheth et al., 1991). Leiper (1995) reveals that travel to different destinations provides consumers with different types of benefits or values, namely emotional, intellectual, spiritual, or physical values.

Tourists will value experiences differently depending on their expectations, the situation, the context, and the resources present (Holbrook, 2006). Williams and Soutar (2009) employ Sheth et al.'s (1991) work as a foundation to measure perceived value, specifically functional, emotional, social, and epistemic value, in an adventure tourism context. The emotional value reflects the product's ability to arouse feelings or affective states and is found to be of particular interest in experiential settings in that emotions largely affect satisfaction evaluations (Otto \& Ritchie, 1996).

Tourism studies disclose that perceived value affects satisfaction positively (e.g., Gallarza \& Soura, 2006; Mohd-Any, Winklhofer, \& Ennew, 2015; Prebensen, Woo, \& Uysal, 2014; Williams \& Soutar, 2009). Among them, Williams and Soutar (2009) study the relationship between perceived value, satisfaction, and behavioural intention. They find that emotional value and novelty value affect satisfaction significantly and suggest that they become even more important than value for money as consumers become more experienced and sophisticated (Bello \& Etzel, 1985; Krippendorf, 1987).

\subsection{Co-creation}

Co-creation behavior is delineated as "the joint, collaborative, concurrent, peer-like process of producing value, both materially and symbolically" (Galvagno \& Dalli, 2014, p. 644) and comprises dimensions such as physical and/or psychological participation (e.g., Prebensen et al., 2016). Prebensen and Foss (2011) show that consumers partake in creating value differently depending on the situation and the actors present. The consumer's own imagination is outlined as a resource in the value-creation process (Prebensen \& Foss, 2011). Rodie and Kleine (2000) categorize value co-creation practices as mental, physical, and emotional participation. Other researchers divide value co-creation into three facets: co-production, engagement, and personalization (Minkiewicz et al., 2013). As can be drawn from the literature, co-creation practices include both physical and psychological magnitudes. 
The perspective of service-dominant logic (SDL) (Vargo \& Lusch, 2004) highlights the concept of co-creation of value, in contrast to the co-production of value, for the following reason. The co-production perspective sees the consumer as a passive agent and focuses on how a firm may benefit from consumer involvement in the production of a service, whereas co-creation is about value creation in consumer-firm relationships in which the consumer is seen as an active agent (e.g., Prahalad \& Ramaswamy, 2004a, 2004b; Vargo \& Lusch, 2004). Following the debate on the imperative of the consumer as an active part in SDL, Vargo and Lusch (2006, p. 44) suggest, "The consumer is always a co-creator of value. There is no value until an offering is used - experience and perception are essential to value determination." Carù and Cova (2007, p. 7) observe that it is "widely accepted within an experiential perspective that consumers are not passive agents reacting to stimuli, but, instead, the actors and producers of their own consuming experiences".

Empirical evidence of the relationships between participating in value creation and satisfaction is increasing. Participating in the production process of a tangible product, such as self-made products, is for instance shown to enhance the value of and satisfaction with the product (Norton, Mochon, \& Ariely, 2012; Troye \& Supphellen, 2011). Norton et al. (2012) even show that consumers find self-made products to be more valuable than those made by experts. Navarro et al. (2016) study spa services and disclose a positive relationship between co-creation and customer satisfaction. Dong, Evans, and Zou (2008) find that participation in service recovery affects tourists' travel satisfaction positively. Mathis, Kim, Uysal, Sirgy, and Prebensen (2016) reveal a positive relationship between tourists' satisfaction with co-creation and their overall satisfaction with the vacation experience. In a similar way, researchers suggest that tourists who participate in co-creation processes will become more satisfied than otherwise (e.g., Grissemann \& Stokburger-Sauer, 2012; Lee, 2012).

Tourism research exposes that co-creation moderates the effect between perceived experience value and satisfaction, confirming that active patrons become significantly more satisfied than passive ones (Prebensen et al., 2016). Prebensen et al.’s study, however, does not take into consideration how the perceived value comes into existence, for instance acknowledging value perception as a mediating factor in the relationship between participation and satisfaction.

\subsection{Mastering}


Fuchs and Schreier (2011) study consumers' involvement in product development and suggest "empowerment" to reflect the skills and effort put into such behaviour, namely mastering. The effort exerted in a consumption process is furthermore shown to increase the overall satisfaction with a tourist experience in a positive way (Prebensen, Vitters $\varnothing, \&$ Dahl, 2013). These findings are in contrast to the general marketing literature, in which consumer inputs, such as time, money, and efforts, are normally regarded as consumers' cost (Zeithaml, 1988) or sacrifice (Cronin et al., 2000).

Co-creation of value implies some sort of capability to perform in a certain way or to engage in a specific behaviour to achieve a desired goal (Vargo \& Lush, 2004). In positive psychology research, skills are depicted as an important antecedent of certain emotional states, that is, eudaimonic feelings, during task engagement (Csikszentmihalyi, 1990; Keller \& Bless, 2008). The "flow model" of motivation claims that, to feel flow, an individual needs to have skills in the respective domain (Csikszentmihalyi, 1990). Flow feelings are a mental state that occurs when there is a balance between skills and challenges (Csikszentmihalyi, 1975). In a study of an adventure sport, mountaineering, Tsaur, Yen, and Hsiao (2013) discuss the concept of mastering as being embedded in flow. Their study reveals that flow affects feelings such as happiness and mediates the effect of transcendent experience on happiness. This process of participating in value creation also includes the individual's willingness (Dong et al., 2008) and ability (Bandura, 1995) to perform the actions required, to manage difficult or novel tasks, and to cope with difficult situations (Kreitner \& Kinicki, 2010). It is about the power that the individual has and the offer to produce that effect (Bandura, 1997), which in this context is creating valuable adventure tourist experiences.

Tourism research discusses different strategies that individuals implement to reduce risk (e.g., Adam, 2015; Horner \& Swarbrook, 2016). In a study of adventure tourism, Plank (2016) investigates ski tourists' revealed risk-taking behaviour and finds that avalanche skiers adopt different information search strategies to ensure mastering capabilities to be willing to take part in the respective activities. Gardiner and Kvek (2016) disclose the importance of previous experiences and cultural background in participating in outdoor tourism activities. Gardiner and Kvek's study shows that safety evaluation includes self-efficacy beliefs regarding the individual's physical ability to participate in the adventure activity experience contrasted with the evaluation of the level of risk and physical challenge that the activity comprises. Consequently, adventure 
tourists' perception of their mastering skills is expected to affect their perceived value and satisfaction.

\subsection{Hypotheses}

The literature suggests relations between consumer participation, consumer perceived value, and satisfaction. Consumer co-creation and mastering enhance consumer perceived value and satisfaction. Perceived value in experiential consumption is multidimensional and identified as an important antecedent to consumers' satisfaction. Based on the literature analysis, the present study puts forward the following hypotheses and presents them in Figure 1, in which participation includes physical co-creation (a), psychological co-creation (b), and mastering (c):

Hypothesis 1: Participation directly enhances satisfaction.

Hypothesis 2: Participation directly enhances perceived value.

Hypothesis 3: Perceived value functions as a mediating factor between participation and satisfaction.

If hypotheses 2 and 3 are true, the following hypothesis should also be true:

Hypothesis 4: Participation indirectly enhances satisfaction by creating perceived value.

Figure 1 here

\section{Data and methods}

\subsection{Data and data analysis}

Data were collected from tourists visiting one of four companies offering winter experiences in northern Norway between mid-January and mid-April 2013. The tourists were approached during their participation in the winter experience. Altogether, four companies operating in adventure tourism, which involved activities in nature such as dog sledding, sea rafting, snow scooter riding, and ice hotel visits, were selected.

The questionnaire applied consists of two sections. The first section includes respondents' personal background and demographics. The second section includes respondents' agreement about each construct in physical and psychological co-creation, self-mastering levels, perceived value of respondents' experiences, and assessment of satisfaction. The questions included in each construct were based on the existing literature in English (see Table 1). All the items were assessed with scales from 1 = "to a very little extent" to 7 = "to a great extent", as suggested by 
the literature. The questionnaire was further translated into Norwegian, refined, and pretested on a group of fifteen academics and ten practitioners who are experts and scholars in tourism and marketing research. With the help of professional translators, the refined questionnaire was translated into English and German, to be used by tourists who speak either language.

A professional consulting company and a group of trained research assistants helped us to conduct the survey. To ensure the representativeness of the companies, we required a minimum of 150 questionnaires from each of them. Altogether 710 questionnaires were collected. Among them 395 questionnaires were fully completed. A large number of missing values occurred in the education and income variables, which might be due to tourists regarding this information as private. A considerable number of missing values was also apparent in the items measuring social value and emotional value. These values might be less familiar or measurable to the tourists than quality value and economic value. The 395 complete observations were used for the modelling in the present study.

Table 1 summarizes the valid variables, using the results of the factor analysis and their theoretical references. Co-creation includes physical and psychological participation in the activity. Physical participation is about an active bodily contribution, and psychological participation is reflected by personal interest in the experience (mentally). Mastering is measured by the tourist's self-perceived knowledge and skills regarding the travelling, the place visited, and the knowledge and skills involved in the trip. The perceived value construct consists of quality, economic, emotional, social, novelty, and knowledge dimensions. Satisfaction is measured by the overall satisfaction with the trip, recommendation of the trip, and recall of the trip (Oliver, 2014).

Table 1 here.

The data analysis used a three-stage procedure. First, exploratory factor analysis (EFA) was conducted to identify the latent constructs underlying a battery of variables measuring perceived value. Although the scales in the constructs of perceived value are based on the existing literature, there is no conclusion on the exact scales that should be included in each construct. Therefore, we conducted EFA just for the purpose of variable reduction. Second, confirmatory factor analysis (CFA) was performed on the mastering and satisfaction factors for the same purpose. The reason for conducting CFA instead of EFA for mastering and satisfaction is that CFA is widely suggested when there is a prior hypothesis about factors of measured variables (Hurley et al., 1997). Finally, for the logistic modelling, the composite variables of mastering, 
perceived value, and satisfaction were generated according to the results provided by the EFA and CFA.

Normality testing revealed that the data had a problem in exhibiting multivariate normality with skewness. Therefore, EFA for perceived value constructs was conducted using a principal axis instead of maximum likelihood (ML) with the SPSS software. CFA for the mastering and satisfaction constructs was performed using maximum likelihood estimation with robust standard errors (MLM) using R programming. The results of EFA in Table 2 suggest that the factors of perceived value and the items are significantly important in each factor. These six factors are quality value, economic value, novelty value, emotional value, social value, and knowledge value, which together explain $69.4 \%$ of the total variance. The CFA results presented in Table 3 suggest the significant items in measuring the mastering and satisfaction factors. The various fit indices, including the normed-fit index (NFI), Tucker-Lewis index (TLI), comparative-fit index (CFI), root mean square residual (RMR), and standardized root mean square residual (SRMR), indicate that the proposed CFA model fits the sample data well. The results of average variance extracted (AVE) and composite reliability (CR) suggest convergent validity for the mastering and satisfaction constructs. The reported heterotrait-monotrait (HTMT) ratio of correlations discrimination correlation between mastering and satisfaction is 0.287 , far below the most conservative criteria of 0.85 (Henseler, Ringle, \& Sarstedt, 2015), suggesting that discriminant validity is established. Therefore, the factors are in general suggested to be reliable and valid.

Table 2 here.

Table 3 here.

\subsection{Econometric model}

The main research method applied in the study is logistic regression. The apparent advantage of the logit model over structural equation modelling (SEM) is that the former does not require the assumption of multivariate normality. Nunkoo, Ramkissoon, and Gursoy (2013) review the use of SEM in 209 articles published in tourism journals between 2001 and 2011. They find that only $17.2 \%$ of the studies discuss or report multivariate normality. However, multivariate normality is the key assumption in SEM, and violation of this assumption produces distorted results. Recently SEM in partial least squares (PLS-SEM) has popularly been used when the data assumption of multivariate normality cannot be made, although PLS-SEM does not strictly require data to be distributed normally. However, as discussed in two popular books (Hair, Hult, 
Ringle, \& Sarstedt, 2016; Vilares, Almeida, \& Coelho, 2010) on PLS-SEM, highly skewed data are a problem. Vilares et al. (2010, p. 302) state that the robustness of the PLS estimation procedure is conspicuous with respect to skewed response distribution. Hair et al. (2016, p. 78) propose that, "as highly skewed data can cause issues in the estimation of significance levels, researchers should ensure that the data are not too far from normal". Another advantage of the logit model over the SEM model is that the estimated marginal effect in the logit model gives the measurable importance of each explanatory variable. The logit model has been widely used by economists and has recently become increasingly popular in marketing and strategy studies (e.g., Lowe \& Parvar, 2004; Rust \& Zahorik, 1993).

Since the respondents were asked to choose between multiple categories that were ranked in order from 1 = "to a very little extent" to 7 = "to a great extent", ordered logit models should be more appropriate to apply in this case. However, the data are highly skewed. The satisfaction variable and five of the six value variables have means above point " 5 " on the seven-point scales that are used. Although multivariate normality is not required in the logit model, we believe that the highly skewed data are a problem when the low-point scales lose their representatives in the sample. Thus, the multinomial variables were transformed into binomial variables following the approach taken by Mehmetoglu (2014). Respondents who scored 5 or below are considered to be less satisfied or to have lower perceived value, and respondents who scored above 5 are considered to be highly satisfied or to have higher perceived value. The negatively skewed data might be the combined result of the reasons discussed by Mehmetoglu (2014) and Williams and Soutar (2009). The former suggests that the problem reflects the respondents' generally positive value perceptions regarding their experiences, and the latter suggests that the problem reflects most respondents probably being at the higher end of the distribution, since they may have felt that it was politically correct to give a more favourable answer. A binomial logit model was therefore applied and estimated by R programming.

The binominal logit model in the present study is as follows:

$$
\mathrm{P}\left(\mathrm{y}_{\mathrm{i}}=1 \mid \mathrm{X}\right)=\Phi\left(\mathrm{Z}_{\mathrm{i}}\right) \quad \mathrm{i}=1, \ldots \mathrm{n}
$$

where $\Phi$ is a logistical cumulative distribution function taking values strictly between zero and one for all real numbers $\mathrm{z}$ (Wooldridge, 2006); $\mathrm{n}=7$ is the number of dependent variables including one satisfaction variable and six value variables, where:

$$
\begin{gathered}
\Phi\left(\mathrm{z}_{\mathrm{i}}\right)=\frac{\mathrm{e}^{\mathrm{z}_{\mathrm{i}}}}{1+\mathrm{e}^{\mathrm{z}_{\mathrm{i}}}} \\
z_{i}=\beta_{i 0}+\boldsymbol{X} \boldsymbol{\beta}_{\boldsymbol{i}} .
\end{gathered}
$$


Equation (3) represents the natural logarithm of the odds that an observation will fall into a category of answer "highly satisfied/valued $=1$ " or "less satisfied/valued $=0$ ". The model was estimated using maximum likelihood techniques (Wooldridge, 2006). The marginal effects of the predictors on the response probability were calculated as:

$$
\frac{d P\left(y_{i}=1\right)}{d x_{j}}=\Phi\left(z_{i}\right)\left(1-\Phi\left(z_{i}\right)\right) \beta_{i j}
$$

The resulting empirical specification for equation (3) is:

$$
\begin{aligned}
& Z_{\text {sat }}=\beta_{1,0}+\beta_{1,1} \text { core }_{1}+\beta_{1,2} \text { core }_{2}+\beta_{1,3} \text { mast }+\beta_{1,4} \text { qual }+\beta_{1,5} \text { econ }+\beta_{1,6} \text { nove }+\beta_{1,7} \text { emot }+ \\
& \beta_{1,8} \text { soci }+\beta_{1,9} \text { know }+\beta_{1,10} \text { geo }_{1}+\beta_{1,11} \text { geo }_{2}+\beta_{1,12} \text { gender }+\beta_{1,13} \text { age }+\beta_{1,14} \text { edu }+\beta_{1,15} \text { income }_{1}+ \\
& \beta_{1,16} \text { income }_{2}+\beta_{1,17} \text { travel }+\beta_{1,18} \text { travelW }+\beta_{1,19} \text { firm }_{2}+\beta_{1,20} \text { firm }_{3}+\beta_{1,21} \text { firm }_{4}
\end{aligned}
$$

$$
\begin{aligned}
& Z_{i}=\beta_{i, 0}+\beta_{i, 1} \text { core }_{1}+\beta_{i, 2} \text { core }_{2}+\beta_{i, 3} \text { mast }+\beta_{i, 10} \text { geo }_{1}+\beta_{i, 11} \text { geo }_{2}+\beta_{i, 12} \text { gender }+\beta_{i, 13} \text { age }+ \\
& \beta_{i, 14} \text { edu }+\beta_{i, 15} \text { income }_{1}+\beta_{i, 16} \text { income }_{2}+\beta_{i, 17} \text { travel }+\beta_{i, 18} \text { travel }+\beta_{i, 19} \text { firm }_{2}+\beta_{i, 20} \text { firm }_{3}+ \\
& \beta_{i, 21} \text { firm }_{4}
\end{aligned}
$$

$$
i=2, \ldots 7
$$

Equation 5 is the satisfaction equation. As suggested by the literature, we assume that satisfaction is affected not only by the perceived value but also by the tourists' participation in the experiences. Perceived value as suggested by the literature is measured by multidimensional constructs consisting of quality value (qual), economic value (econ), novelty value (nove), emotional value (emot), social value (soci), and knowledge value (know). Participation includes physical ( core $\left._{1}\right)$ and psychological co-creation ( core $\left._{2}\right)$ and self-mastering (mast). If the estimated parameters of core $_{1}$, core $_{2}$, and mast are positive and statistically significant at an acceptable level (normally 10\%), we can conclude that hypothesis $\mathrm{H} 1$ is true, meaning that participation has a positive and direct effect on satisfaction.

Equation 6 represents six value equations. Each perceived value is predicted by tourists' physical ( core $\left._{1}\right)$ and psychological co-creation ( core $\left._{2}\right)$ and mastering (mast). Similarly, if the estimated parameters of core $_{1}$, core $e_{2}$, and mast are positive and statistically significant in equation 6 , we can conclude that participation creates perceived value and hypothesis $\mathrm{H} 2$ is true. While equation 5 captures the direct effects of participation on satisfaction, equation 6 captures its indirect effects on satisfaction via perceived value. If the estimated parameters of the perceived value variables in equation 5 are significantly positive and $\mathrm{H} 2$ tested by equation 6 is also true, we can conclude that perceived value is a mediating variable between participation and satisfaction, and $\mathrm{H} 3$ is therefore true. As we mentioned earlier, if $\mathrm{H} 2$ and $\mathrm{H} 3$ are true, $\mathrm{H} 4$ is 
obviously true, and we can conclude that participation has a positive and indirect influence on satisfaction by creating perceived value.

The remaining variables are controlling variables, including tourists' individual demographic characteristics, their earlier holiday experiences, and the different activities in which they have participated. Specifically, $\mathrm{geo}_{1}$ and $\mathrm{geo}_{2}$ are dummy variables for tourists' places of residence: 1 means tourists from Scandinavian countries, and 2 means tourists from other European countries. The base is tourists from all other countries. The variables income $_{1}$ and income $_{2}$ are dummies for different income levels. The variable travelN represents those who have taken a holiday in northern Norway before, and travelW represents those who have had holiday trips to all destinations more than five times. The variable firm $_{i}$ is a dummy variable to denote the firms that are operating the various activities in which the tourists have participated.

\section{Discussion and conclusion}

The present paper shows the importance of acknowledging mastering and co-creation as crucial variables that affect tourists' perceived value and satisfaction. As illustrated by equation (3), the estimated parameters in the logit model are interpreted as the marginal effects of the observed explanatory variables on the logarithm of odds of success. In the present study, success is interpreted as consumers who are highly satisfied with or who give high value to their experiences. The marginal effects of the explanatory variables on the odds of success are usually reported in business studies, because it is sufficient to find out which explanatory variables are important, but we find it more interesting and straightforward to study the direct effect of variables on the probability of success. The direct effect can be estimated according to equation (4). Thus, instead of reporting the estimated parameters, we present the variables' marginal effect on success probability in Table 4.

In the satisfaction equation, we find that novelty value, emotional value, and social value significantly influence tourists' satisfaction. This result indicates that satisfaction largely transpires through the experience of value (i.e., satisfaction transpires through the value created in and during the experiential encounter). Specifically, when the scale of learning value, emotional value, and social value increases by one unit, it enhances the probability that tourists will be highly satisfied by $6.5 \%, 5.7 \%$, and $2.2 \%$, respectively. Interestingly, we find that quality value and economic value are not statistically important. This finding is consistent with Williams and Soutar's (2009) research in adventure tourism. They explain that the reason that the 
sociological and psychological value dimensions are more important than "value for money" is because, in the adventure tourism domain, hedonism and the pursuit of emotional highs are key motivators. Adventure travellers, who are demanding and discerning consumers, travel to some of the most remote, extreme environments of the world to satisfy their needs for emotional highs, risk, challenge, excitement, and novelty (Bello \& Etzel, 1985; Christiansen, Miles, \& Priest, 1990; Zuckerman, 1994).

The estimated parameters of physical co-creation, psychological co-creation, and mastering are not statistically significant in the satisfaction equation, suggesting that hypothesis $1(\mathrm{H} 1)$ is rejected. Therefore, we conclude that participation is not important in directly influencing tourists' satisfaction. Tourists will not simply feel more satisfied unless they participate in creating a certain kind of value. There are six mastering variables and twelve co-creation variables across the six value equations, in which the estimated marginal effects of all the mastering variables and eight of the twelve co-creation variables are positive and significant. These results suggest that hypothesis 2 is generally true. Literally, co-creation and mastering directly enhance tourists' perceived value.

The estimated results suggest that the psychological co-creation of being interested in an experience will increase the probability of tourists experiencing enhanced quality value (i.e., functional value), economic value, novelty value, emotional value, social value, and knowledge value by $7.4 \%, 10.2 \%, 9.1 \%, 10.3 \%, 12.7 \%$, and $8.7 \%$, respectively. The estimated parameters of physical co-creation are statistically significant in the novelty value and emotional value equations, but not in the others. All the estimated marginal effects of the psychological (i.e., of the mental co-creation) variable are significant, while only two of them are significant in the six physical co-creation estimators. In addition, the magnitude of the estimated marginal effects of psychological co-creation is larger than the magnitude of the effect of physiological co-creation. These results suggest that psychological co-creation is more important than physical co-creation in enhancing perceived experience value in tourism. This finding is reasonable, since in tourism, particularly adventure tourism, psychological value is found to be more important than physiological value (Nordb $\varnothing \&$ Prebensen, 2015), and the main motivation for tourists to take holidays is to find something emotional and to experience something novel (e.g., Bello \& Etzel, 1985).

We also found that mastering is very important in generating experience value. When a tourist has good skills and prior experience, he or she gains more value from the experienced activities. 
Similar to our finding regarding the effects of co-creation, mastering has a greater influence on sociological and psychological values than on physiological values. Specifically, the marginal effects of the mastering variable on the probability of tourists feeling high social value and knowing value are $10.1 \%$ and $12 \%$, respectively, whereas the marginal effects of the mastering variable on the probability of tourists feeling high quality value and economic value are only $2.7 \%$ and $7.1 \%$, respectively.

Since $\mathrm{H} 2$ is generally true and the estimated parameters of novelty value, emotional value, and social value are significantly positive in the satisfaction equation, this means that $\mathrm{H} 3$ is also true. This finding recognizes the importance of acknowledging tourists' perceived experience value as a mediator in the relationship between co-creation, mastering, and satisfaction. As discussed earlier, when $\mathrm{H} 2$ and $\mathrm{H} 3$ are true, $\mathrm{H} 4$ is also true. The result confirms our assumption that cocreation and mastering are more important in increasing tourists' perceived experience value and hence indirectly increase satisfaction via value variables than in affecting satisfaction directly. The findings further suggest that consumers' self-perceived mastering and psychological cocreation are highly relevant to their value perceptions and satisfaction evaluations in experiential consumption. Also of interest is the result that psychological co-creation is more important than physical co-creation. This finding is in line with Williams and Soutar (2009), who find that the psychological points are more valued by consumers in adventure tourism.

Based on the findings of the present work, adventure tourism companies should focus on involving and motivating tourists to participate in operated activities, and special attention should be given to tourists' psychological participation. This should be combined with analysis and programmes tailored to meet the knowledge and skills of different customer groups. In the tourists' participation process, it is imperative for firms to facilitate and communicate the possible values created by activities with tourists. Among the different values, spiritual types of value, such as novelty, emotional, and social value, should be emphasized to enhance adventure tourists' overall satisfaction.

The main contributions to the theory by the present work are the inclusion of mastering as central in acknowledging consumers as a resource integrator and the identification of consumers' psychological participation overriding their physical participation in influencing their perceived value and consequently their overall satisfaction. In addition, the study identifies the mediating effect of perceived value between participation and satisfaction. Furthermore, the study confirms 
Williams and Soutar's (2009) finding that, in the adventure tourism context, spiritual or psychosocial value is more important than conventional economic value and functional value.

The present work adds to the empirical experiential research in several ways. First, by testing the suggested model in an adventure tourism setting, the study provides new knowledge to the tourism industry. From a managerial standpoint, this study emphasizes perceived value in experiential consumption as imperative, in particular with regard to facilitating consumer participation in creating value. Firms may benefit from the facilitation and implementation of a consumer involvement strategy and from ensuring that the consumers have the right skills and knowledge to partake in creating the preferred value.

In spite of the contributions of the present paper, there are some limitations. First, adventure tourists in a specific geographic area were targeted, calling for further studies in other industries and settings. Second, physical and psychological co-creation were measured by single items only. To enhance the validity and reliability of the co-creation dimensions, in-depth studies in experiential consumption settings should be carried out in addition to adopting and adjusting the existing scales (e.g., Yi \& Gong, 2013). There might be reciprocal relations between cocreation and mastering that need further study.

Further research is needed to explore the "adventure" dimension in more detail. While the cocreation, mastering, and value framework used in the present study was contextualized towards adventure tourism, there may be other specific participation dimensions and value perception dimensions that are relevant to adventure tourism practices. As the present work suggests, more knowledge regarding the search for eudaimonic feelings in adventure consumption is needed.

Based on the findings of the present work, adventure tourism companies should focus on involving and motivating tourists by facilitating and communicating novelty, emotional, and social value in addition to conducting various educational programmes ensuring mastering by customers. This should be combined with analysis and programmes tailored to the knowledge and skills of different customer groups. Furthermore, firms need to satisfy the physical and psychological needs and perceived value of the tourists. Above all, it is imperative for firms to acknowledge and develop programmes to enhance perceived value by customer participation in co-creating novelty, emotional, and social value to enhance their overall satisfaction. 


\section{References}

Adam, I. (2015). Backpackers' risk perceptions and risk reduction strategies in Ghana. Tourism Management, 49, 99-108.

Addis, M., \& Holbrook, M. B. (2001). On the conceptual link between mass customization and experiential consumption: An explosion of subjectivity. Journal of Consumer Behaviour, $1(1), 50-66$.

Ajzen, I. (1991). The theory of planned behavior. Organizational Behavior and Human Decision Processes, 50(2), 179-211.

Bandura, A. (1992). Exercise of personal agency through the self-efficacy mechanism. In R. Schwarzer (Ed.), Self-efficacy: Thought control of action (pp. 3-38). Washington, DC: Hemisphere.

Bandura, A. (1993). Perceived self-efficacy in cognitive development and functioning. Educational Psychologist, 28(2), 117-148.

Bandura, A. (1995). Exercise of personal and collective efficacy in changing societies. In A. Bandura (Ed.), Self-efficacy in changing societies (pp. 1-45). New York, NY: Cambridge University Press.

Bandura, A. (1997). Self-efficacy: The exercise of control. New York, NY: Freeman.

Baron, S., \& Harris, K. (2008). Consumers as resource integrators. Journal of Marketing Management, 24(1-2), 113-130. doi: 10.1362/026725708X273948

Bello, D. C., \& Etzel, M. J. (1985). The role of novelty in the pleasure travel experience. Journal of Travel Research, 24(1), 20-26.

Bertella, G. (2014). The co-creation of animal-based tourism experience. Tourism Recreation Research, 39(1), 115-125. doi: 10.1080/02508281.2014.11081330

Borsboom, D., Mellenbergh, G. J., \& Heerden, J, V. (2004). The concept of validity. Psychological Review, 111(4), 1061-1071.

Campos, A. C., Mendes, J., Oom do Valle, P., \& Scott, N. (2016). Co-creation experiences: Attention and memorability. Journal of Travel \& Tourism Marketing. doi: $10.1080 / 10548408.2015 .1118424$

Carù, A., \& Cova, B. (2003). Revisiting consumption experience: A more humble but complete view of the concept. Marketing Theory, 3(2), 267-286.

Carù, A., \& Cova, B. (2007). Consuming experiences: An introduction. In A. Carù \& B. Cova (Eds.), Consuming experience (pp. 3-16). Abingdon, UK: Routledge. 
Christiansen, D. R., Miles, J. C., \& Priest, S. (1990). Adventure tourism. State College, PA: Adventure Education, Venture Publishing.

Constantin, J. A., \& Lusch, R. F. (1994). Understanding resource management. Oxford, OH: The Planning Forum.

Cronin, J. J., Brady, M. K., \& Hult, G. T. M. (2000). Assessing the effects of quality, value, and customer satisfaction on consumer behavioral intentions in service environments. Journal of Retailing, 76(2), 193-218.

Csikszentmihalyi, M. (1975). Beyond boredom and anxiety. San Francisco: Jossey-Bass.

Csikszentmihalyi, M. (1990). Flow: The psychology of optimal experience. New York: Harper Perennial.

Dong, B., Evans, K. R., \& Zou, S. (2008). The effects of customer participation in co-created service recovery. Journal of the Academy of Marketing Science, 36(1), 123-137.

Doyle, P. (1997). The application of Probit, Logit, and Tobit in marketing: A review. Journal of Business Research, September, 235-248.

Gallarza, M. G., \& Saura, I. G. (2006). Value dimensions, perceived value, satisfaction and loyalty: An investigation of university students' travel behaviour. Tourism Management, $27,437-452$.

Galvagno, M., \& Dalli, D. (2014). Theory of value co-creation: A systematic literature review. Managing Service Quality, 24(6), 643-683.

Gardiner, S., \& Kwek, A. (2016). Chinese participation in adventure tourism: A study of Generation Y international students' perceptions. Journal of Travel Research, 0047287516646221.

Grönroos, C. (2011). Value co-creation in service logic: A critical analysis. Marketing Theory, 11(3), 279-301.

Grönroos, C., \& Voima, P. (2013). Critical service logic: Making sense of value creation and co creation. Journal of the Academy of Marketing Science, 41(2), 133-150.

Hair, J. F., Hult, G. T. M., Ringle, C. M., \& Sarstedt, M. (2016). A primer on partial least squares structural equation modeling (PLS-SEM). Thousand Oaks, CA: Sage.

Henseler, J., Ringle, C. M., \& Sarstedt, M. (2015). A new criterion for assessing discriminant validity in variance-based structural equation modeling. Journal of the Academic Marketing Science, 43, 115-135. 
Hirschman, E. C., \& Holbrook, M. B. (1982). Hedonic consumption: Emerging concepts, methods, and propositions. Journal of Marketing, 46, 92-101.

Ho, S. H., \& Ko, Y. Y. (2008). Effects of self-service technology on customer value and customer readiness: The case of Internet banking. Internet Research, 18(4), 427-446.

Holbrook, M. B. (1987). What is consumer research? Journal of Consumer Research, 14(June), $128-132$.

Holbrook, M. B. (2000). The millennial consumer in the texts of our times: Experience and entertainment. Journal of Macromarketing, 20(2), 178-192.

Holbrook, M. B. (2006). ROSEPEKICECIVECI versus CCV: The resource-operant, skillsexchanging, performance-experiencing, knowledge-informed, competence-enacting, coproducer-involved, value-emerging, customer-interactive view of marketing versus the concept of customer value: "I can get it for you wholesale". In R. F. Lush \& S. L. Vargo (Eds.), The service-dominant logic of marketing: Dialog, debate and directions (pp. 20823). Armonk, NY: M. E. Sharpe.

Holbrook, M. B., \& Hirschman, E. C. (1982). The experiential aspects of consumption: Consumer fantasies, feelings, and fun. Journal of Consumer Research, 9(2), 132-140.

Horner, S., \& Swarbrooke, J. (2016). Consumer behaviour in tourism. London: Routledge.

Hurley, A. E., Scandura, T. A., Schriesheim, C. A., Brannick, M. T., Seers, A., Vandenberg, R. T., \& Williams, L. J. (1997). Exploratory and confirmatory factor analysis: Guideline, issues, and alternatives. Journal of Organizational Behavior, 18(6), 667-683.

Keller, J., \& Bless, H. (2008). Flow and regulatory compatibility: An experimental approach to the flow model of intrinsic motivation. Journal of Personality and Social Psychology Bulletin, 34, 196-209. doi: 10.1177/0146167207310026

Kolb, D. A. (1984). Experiential learning: Experience as the source of learning and development. Englewood Cliffs, NJ: Prentice Hall.

Kreitner, R., \& Kinicki, A. (2010). Organizational behavior (9th ed.). New York, NY: McGraw-Hill.

Krippendorf, J. (1987). Ecological approach to tourism marketing. Tourism Management, 8, 174176.

Leiper, N. (1995). Tourism management. Melbourne: RMIT Publishing.

Lowe, D. J., \& Parvar, J. (2004). A logistic regression approach to modelling the contractor's decision to bid. Construction Management and Economics, 22(6), 643-653. 
Martin, P., \& Priest, S. (1986). Understanding the adventure experience. Adventure Education, $3(1), 18-21$.

Mathis, E. F., Uysal, M., Sirgy, J., \& Prebensen, N. K. (2016). The effect of co-creation experience on outcome variable. Annals of Tourism Research, 57, 62-75.

Mehmetoglu, M. (2014). Predictors of sustainable consumption in a tourism context: A CHAID approach. In J. S. Chen (Ed.), Advances in hospitality and leisure (pp. 3-23). Bingley, UK: Emerald Group Publishing Limited.

Minkiewicz, J., Evans, J., \& Bridson, K. (2014). How do consumers co-create their experiences? An exploration in the heritage sector. Journal of Marketing Management, 30(1-2), 30-59.

Mohd-Any, A. A., Winklhofer, H., \& Ennew, C. (2015). Measuring users' value experience on a travel website (e-value): What value is cocreated by the user? Journal of Travel Research, 54(4), 496-510.

Nambisan, S., \& Baron, R. A. (2009). Different roles, different strokes: Organizing virtual customer environments to promote two types of customer contributions. Organization Science, 21(2), 554-572.

Navarro, S., Andreu, L., \& Cervera, A. (2014). Value co-creation among hotels and disabled customers: An exploratory study. Journal of Business Research, 67(5), 813-818.

Navarro, S., Llinares, C., \& Garzon, D. (2016). Exploring the relationship between co-creation and satisfaction using QCA. Journal of Business Research, 69(4), 1336-1339.

Nordbø, I., \& Prebensen, N. K. (2015). Hiking as mental and physical experience. In J. S. Chen (Ed.), Advances in hospitality and leisure (11) (pp. 169-186). Emerald Group Publishing Limited.

Norton, M. I., Mochon, D., \& Ariely, D. (2012). The IKEA effect: When labor leads to love. Journal of Consumer Psychology, 22, 453-460.

Nunkoo, R., Ramkissoon, H., \& Gursoy, D. (2013). Use of structural equation modeling in tourism research past, present and future. Journal of Travel Research, 52(6), 759-771.

Oliver, R. L. (2014). Satisfaction. A behavioral perspective on the consumer (2nd ed.). London: Routledge, Taylor \& Francis Group.

Panksepp, J. (2005). Affective consciousness: Core emotional feelings in animals and humans. Consciousness and Cognition, 14(1), 30-80. 
Plank, A. (2016). The hidden risk in user-generated content: An investigation of ski tourers' revealed risk-taking behavior on an online outdoor sports platform. Tourism Management, 55, 289-296.

Prahalad, C. K., \& Ramaswamy, V. (2004a). The future of competition: Co-creating unique value with customers. Boston, MA: Harvard Business School Press.

Prahalad, C. K., \& Ramaswamy, V. (2004b). Co-creation experiences: The next practice in value creation. Journal of Interactive Marketing, 18(3), 5-14.

Prebensen, N. K., \& Foss, L. (2011). Coping \& cocreating in tourist experiences. International Journal of Tourism Research, 13, 54-67. doi: 10.1002/jtr.799

Prebensen, N. K., Kim, H., \& Uysal, M. S. (2016). Co-creation as moderator between the experience value and satisfaction relationship. Journal of Travel Research, 5(7), 934-945.

Prebensen, N. K., Dahl, T., \& Vitters $\varnothing$, J. (2013). Value co-creation. Significance of tourist resources. Annals of Tourism Research, 42, 240-261.

Prebensen, N. K., Woo, E., \& Uysal, M. S. (2014). Experience value: Antecedents and consequences. Current Issues in Tourism, 17(10), 910-928.

Rihova, I., Buhalis, D., Moital, M., \& Gouthro, M. B. (2015). Conceptualising customer-tocustomer value co-creation in tourism. International Journal of Tourism Research, 17(4), $356-363$.

Rodie, A., \& Kleine, S. (2000). Consumer participation in services production and delivery. In T. Swartz \& D. Iacobucci (Eds.), Handbook of services, marketing and management (pp. 111125). Thousand Oaks, CA: Sage.

Rust, R. T., \& Zahorik, A. J. (1993). Customer satisfaction, customer retention, and market share. Journal of Retailing, 69(2), 193-215.

Sheth, J. N., Newman, B. I., \& Gross, B. L. (1991). Consumption values and market choice. Cincinnati, OH: South Western Publishing.

Sung, H. H., Morrison, A. M., \& O’Leary, J. T. (1996). Definition of adventure travel: Conceptual framework for empirical application from the providers' perspective. Asia Pacific Journal of Tourism Research, 1(2), 47-67.

Tinsley, H. (1979). The latent structure of the need satisfying properties of leisure activities. Journal of Leisure Research, 11, 278-291. 
Troye, S. V., \& Supphellen, M. (2012). Consumer participation in coproduction: "I made it myself" effects on consumers' sensory perceptions and evaluations of outcome and input product. Journal of Marketing, 76(2), 33-46.

Tsaur, S.-H., Yen, C.-H., \& Hsiao, S.-L. (2013). Transcendent experience, flow and happiness for mountain climbers. International Journal of Tourism Research, 15, 360-374.

Vargo, S. L., \& Lusch, R. F. (2004). Evolving to a new dominant logic of marketing. Journal of Marketing, 68(1) (January), 1-17.

Vargo, S. L., \& Lusch, R. F. (2006). Service-dominant logic: What it is, what it is not, what it might be. In R. F. Lusch \& S. L. Vargo (Eds.), The service-dominant logic of marketing: Dialog, debate and directions (pp. 43-56). Armonk, NY: M. E. Sharpe.

Verhoef, P. C., Reinartz, W. J., \& Krafft, M. (2010). Customer engagement as a new perspective in customer management. Journal of Service Research, 13(3), 247-252.

Vilares, M. J., Almeida, M. H., \& Coelho, P. S. (2010). Comparison of likelihood and PLS estimators for structural equation modeling: A simulation with customer satisfaction data. In V. Esposito Vinzi, W. W. Chin, J. Henseler, \& H. Wang (Eds.), Handbook of partial least squares: Concepts, methods and applications (pp. 289-305). New York: Springer.

Vitters $\varnothing$, J. (2011). Recreate or create? Leisure as an arena for recovery and change. In Positive psychology as social change (pp. 293-308). The Netherlands: Springer.

Walle, A. H. (1997). Pursuing risk or insight: Marketing adventures. Annals of Tourism Research, 24, 265-282.

Williams, P., \& Soutar, G. N. (2009). Value, satisfaction and behavioral intentions in an adventure tourism context. Annals of Tourism Research, 36(3), 413-438.

Wooldridge, J. M. (2006). Introduction econometrics: A modern approach. Mason, USA: Thomson South-Western.

Yi, Y., \& Gong, T. (2013). Customer value co-creation behavior: Scale development and validation. Journal of Business Research, 66, 1279-1284.

Zeithaml, V. A. (1988). Consumer perceptions of price, quality and value: A means-end model and synthesis of evidence. Journal of Marketing, 52(3), 2-22.

Zuckerman, M. (1994). Behavioral expressions and biosocial bases of sensation seeking. Cambridge: Cambridge University Press. 
Table 1. Valid variables for logit regression

\begin{tabular}{|c|c|c|c|}
\hline Variable & Dimension & Authors & $\begin{array}{c}\text { Operationalized in the } \\
\text { present survey }\end{array}$ \\
\hline Co-creation & $\begin{array}{l}\text { - } \\
\text { - Cogysical participation } \\
\text { participation }\end{array}$ & $\begin{array}{l}\text { Carù and Cova (2007) } \\
\text { Prebensen and Foss } \\
\text { (2011) }\end{array}$ & $\begin{array}{l}\text { - I am an active } \\
\text { participant in this } \\
\text { experience. } \\
\text { - I am interested in } \\
\text { this experience. }\end{array}$ \\
\hline $\begin{array}{l}\text { Self- } \\
\text { perceived } \\
\text { mastering }\end{array}$ & $\begin{array}{l}\text { Knowledge about } \\
\text { travelling } \\
\text { - Knowledge about the } \\
\text { place } \\
\text { - Skills for the trip }\end{array}$ & $\begin{array}{l}\text { Tsaur, Yen, and Hsiao } \\
\text { (2013) }\end{array}$ & $\begin{array}{l}\text { - In general, I am a } \\
\text { very experienced } \\
\text { traveller. } \\
\text { - I know a lot } \\
\text { about the culture } \\
\text { and nature in this } \\
\text { area. } \\
\text { I know a lot } \\
\text { about this type of } \\
\text { experience. } \\
\text { I handle this type } \\
\text { of experience } \\
\text { extremely well. }\end{array}$ \\
\hline $\begin{array}{l}\text { Value } \\
\text { perception }\end{array}$ & $\begin{array}{ll}\text { - } & \text { Functional (quality) } \\
\text { - } & \text { Functional } \\
\text { - } & \text { Economic) } \\
\text { - } & \text { Social } \\
\text { - } & \text { Epistemic (novelty } \\
& \text { and learning) }\end{array}$ & $\begin{array}{l}\text { Sheth et al. (1991) } \\
\text { Williams and Soutar } \\
\text { (2009) }\end{array}$ & - $\quad$ See Table 2 \\
\hline Satisfaction & $\begin{array}{l}\text { - Overall satisfaction } \\
\text { with the trip } \\
\text { - Recommendations }\end{array}$ & Oliver (2014) & $\begin{array}{l}\text { - It has been a } \\
\text { good experience. } \\
\text { - I will always }\end{array}$ \\
\hline
\end{tabular}




\begin{tabular}{|l|l|l|l|}
\hline & & $\begin{array}{l}\text { remember this } \\
\text { experience. }\end{array}$ \\
& & I will recommend \\
& this experience to \\
& & $\begin{array}{l}\text { others. } \\
\text { I enjoy } \\
\end{array}$ & $\begin{array}{l}\text { discussing this } \\
\text { type of holiday } \\
\end{array}$ \\
& with my friends. \\
\hline
\end{tabular}


Table 2. EFA analysis of perceived value

\begin{tabular}{|c|c|c|c|}
\hline Perceived value & $\begin{array}{l}\text { Factor } \\
\text { loading }\end{array}$ & Eigenvalue & $\begin{array}{l}\text { Variance } \\
\text { explained }\end{array}$ \\
\hline Quality value & & 9.4 & 14.5 \\
\hline This winter experience has a consistent level of quality. & 0.85 & & \\
\hline This winter experience is well formed. & 0.85 & & \\
\hline This experience has an acceptable standard of quality. & 0.74 & & \\
\hline This experience is well organized. & 0.74 & & \\
\hline Economic value & & 2.8 & 12.8 \\
\hline This winter experience is correctly priced. & 0.87 & & \\
\hline The prices for additional services are acceptable. & 0.86 & & \\
\hline This experience represents "value" for money. & 0.70 & & \\
\hline \multirow[t]{2}{*}{ The price paid for this experience is reasonable. } & 0.64 & & \\
\hline & & 2.0 & 12.7 \\
\hline \multicolumn{4}{|l|}{ Novelty value } \\
\hline This winter experience is unique. & 0.75 & & \\
\hline This is a once-in-a-lifetime experience. & 0.69 & & \\
\hline This winter experience is educational. & 0.62 & & \\
\hline This winter experience satisfies my curiosity. & 0.61 & & \\
\hline $\begin{array}{l}\text { This winter experience provides an authentic/genuine } \\
\text { experience. }\end{array}$ & 0.55 & & \\
\hline Emotional value & & 1.3 & 10.7 \\
\hline This winter experience makes me happy. & 0.73 & & \\
\hline This winter experience is stimulating. & 0.72 & & \\
\hline This winter experience is exciting. & 0.65 & & \\
\hline This winter experience gives me a feeling of well-being. & 0.54 & & \\
\hline Social value & & 1.1 & 10.0 \\
\hline $\begin{array}{l}\text { Participating in this winter experience enables me to } \\
\text { impress other people. }\end{array}$ & 0.89 & & \\
\hline
\end{tabular}


Participating in this winter experience makes me feel

more socially accepted. $\quad 0.76$

Participating in this winter experience enables me to

create a good impression.

0.70

\section{Knowledge value}

1.1

8.8

Learning is a key to valuable experience in the future.

0.77

Learning is an investment, not an expense.

0.77

I have participated in something meaningful here.

0.54

Total variance

69.4

Note: Kaiser-Meyer-Olkin index $=0.914$, Bartlett's test of sphericity $=6657.259$, df $=253(\mathrm{p}$ $=.000)$. 


\begin{tabular}{|c|c|c|c|c|}
\hline & $\begin{array}{c}\text { Standardized } \\
\text { loading }\end{array}$ & $\begin{array}{c}\text { Z- } \\
\text { value }\end{array}$ & $\begin{array}{l}\text { Composite } \\
\text { reliability } \\
(\mathrm{CR})\end{array}$ & $\begin{array}{c}\text { Average } \\
\text { variance } \\
\text { extracted } \\
\text { (AVE) }\end{array}$ \\
\hline Self-perceived mastering & & & 0.83 & 0.59 \\
\hline \multicolumn{5}{|l|}{ In general, I am a very experienced } \\
\hline traveller. & 0.513 & - & & \\
\hline \multicolumn{5}{|l|}{ I know a lot about the culture and nature } \\
\hline in this area. & 0.865 & 12.07 & & \\
\hline \multicolumn{5}{|l|}{ I know a lot about this type of } \\
\hline experience. & 0.919 & 12.53 & & \\
\hline \multicolumn{5}{|l|}{ I handle this type of experience } \\
\hline extremely well. & 0.509 & 9.33 & & \\
\hline Satisfaction & & & 0.88 & 0.64 \\
\hline It has been a good experience. & 0.831 & - & & \\
\hline I will always remember this experience. & 0.859 & 17.74 & & \\
\hline I will recommend this experience to & & & & \\
\hline others. & 0.927 & 21.19 & & \\
\hline \multicolumn{5}{|l|}{ I enjoy discussing this type of holiday } \\
\hline with my friends. & 0.636 & 13.47 & & \\
\hline
\end{tabular}


Table 4. Estimated results of the marginal effects on the probability of being highly satisfied/valued

\begin{tabular}{|c|c|c|c|c|c|c|c|}
\hline & Satisfaction & $\begin{array}{l}\text { Quality } \\
\text { value }\end{array}$ & $\begin{array}{l}\text { Economic } \\
\text { value }\end{array}$ & $\begin{array}{l}\text { Novelty } \\
\text { value }\end{array}$ & $\begin{array}{l}\text { Emotional } \\
\text { value }\end{array}$ & $\begin{array}{l}\text { Social } \\
\text { value }\end{array}$ & $\begin{array}{l}\text { Knowledge } \\
\text { value }\end{array}$ \\
\hline \multirow[t]{2}{*}{ Intercept } & -1.063 & -0.339 & -1.337 & -0.993 & -0.836 & -1.449 & -1.186 \\
\hline & $(-4.76)$ & $(-1.71)$ & $(-5.64)$ & $(-4.76)$ & $(-5.08)$ & $(-6.41)$ & $(-5.32)$ \\
\hline \multicolumn{8}{|l|}{ Physical } \\
\hline \multirow[t]{2}{*}{ co-creation } & -0.001 & 0.023 & 0.043 & $0.061 * *$ & $0.040 * *$ & 0.030 & 0.036 \\
\hline & $(-0.06)$ & $(1.54)$ & $(1.50)$ & $(2.32)$ & (2.07) & (1.03) & $(1.28)$ \\
\hline \multicolumn{8}{|l|}{ Mental } \\
\hline \multirow[t]{2}{*}{ co-creation } & -0.001 & $0.074 * *$ & $0.102^{* *}$ & $0.091 * *$ & $0.103 * *$ & $0.127 * *$ & $0.087 * *$ \\
\hline & $(-0.06)$ & $(3.06)$ & (2.95) & (2.99) & $(4.22)$ & (3.49) & $(2.59)$ \\
\hline \multirow[t]{2}{*}{ Mastering } & 0.020 & $0.027 * *$ & $0.071^{* *}$ & $0.066 * *$ & $0.035^{* *}$ & $0.101 * *$ & $0.120 * *$ \\
\hline & $(1.37)$ & $(2.18)$ & $(3.60)$ & $(3.78)$ & $(2.42)$ & $(5.26)$ & $(6.00)$ \\
\hline \multirow[t]{2}{*}{ Quality value } & 0.028 & - & - & - & - & - & - \\
\hline & $(0.99)$ & & & & & & \\
\hline \multirow[t]{2}{*}{ Economic value } & 0.006 & - & - & - & - & - & - \\
\hline & $(0.46)$ & & & & & & \\
\hline \multirow[t]{2}{*}{ Novelty value } & $0.065 * *$ & - & - & - & - & - & - \\
\hline & $(2.97)$ & & & & & & \\
\hline \multirow[t]{2}{*}{ Emotional value } & $0.057 * *$ & - & - & - & - & - & - \\
\hline & $(2.22)$ & & & & & & \\
\hline \multirow[t]{2}{*}{ Social value } & $0.022^{*}$ & - & - & - & - & - & - \\
\hline & $(1.65)$ & & & & & & \\
\hline \multirow[t]{2}{*}{ Knowledge value } & 0.006 & - & - & - & - & - & - \\
\hline & $(0.39)$ & & & & & & \\
\hline
\end{tabular}

Note: The numbers in parentheses are asymptotic t-rations. ${ }^{*}=$ significant at the $5 \%$ level; $*=$ significant at the $10 \%$ level. We have omitted the estimated results to save space. 


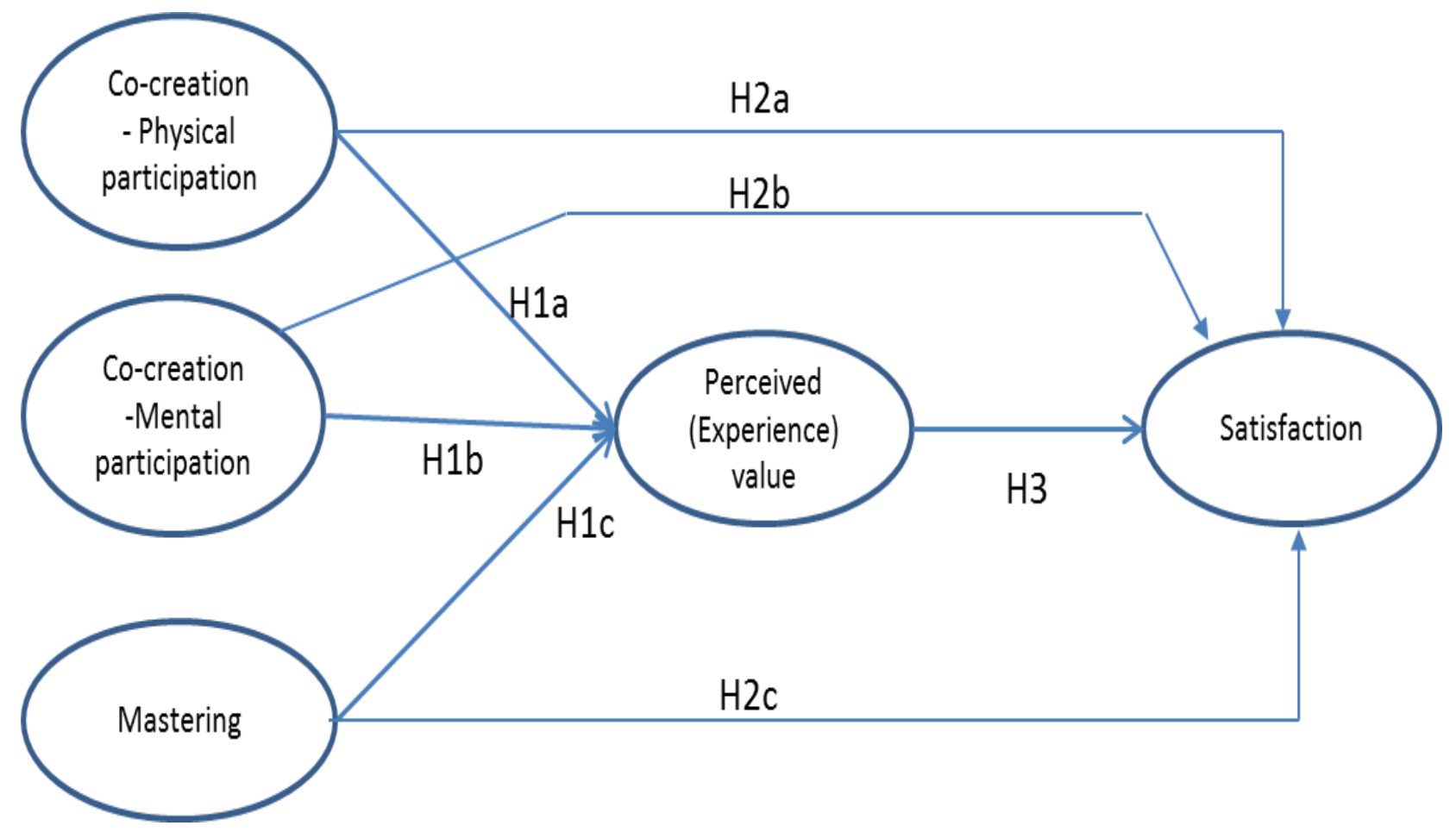

Figure 1. Illustration of the developed hypotheses 